\title{
Millepora alcicornis (Hydrozoa: Capitata) at Ascension Island: confirmed identity based on morphological and molecular analyses
}

\author{
BERT W. HOEKSEMA ${ }^{1}$, FLAVIA L. D. NUNES ${ }^{2}$, ALBERTO LINDNER ${ }^{3}$ AND JÚliA NUNES DE SOUZA ${ }^{3}$ \\ ${ }^{1}$ Department of Marine Zoology, Naturalis Biodiversity Center, P.O. Box 9517, 2300 RA Leiden, the Netherlands, ${ }^{2}$ Institut \\ Universitaire Européen de la Mer, Université de Bretagne Occidentale, Technopole Brest-Iroise, 29280 Plouzané, France, \\ ${ }^{3}$ Departamento de Ecologia e Zoologia, Universidade Federal de Santa Catarina, Florianópolis, SC 88040-970, Brazil
}

\begin{abstract}
The reef-building fire coral Millepora alcicornis is reported from Ascension Island (South Atlantic). This record, based on a recent expedition to Ascension, is the first in which the identification of a Millepora coral is supported by photographic evidence from the field and by morphological and molecular analyses of collected specimens. This finding is discussed in relation to earlier Millepora records from Ascension and the biogeographic range of this particular species in the Atlantic.
\end{abstract}

Keywords: fire coral, distribution range, isolation, morphology, molecular analysis, South Atlantic

Submitted 7 February 2014; accepted 7 August 2014; first published online 16 October 2014

\section{INTRDDUCTION}

Millepora is a hydrozoan genus of so-called 'fire corals', which are well known for inflicting painful stings to humans and for being important reef-builders because of their large calcareous skeletons (Lewis, 2006). The distribution of this genus is limited to $50 \mathrm{~m}$ depth in tropical seas (Lewis, 1989, 2006; Cairns et al., 1999), with a clear distinction between species in the Atlantic (Amaral et al., 2002, 2008) and the Indo-Pacific (Razak \& Hoeksema, 2003). There are seven recognized species in the Atlantic Ocean, which can be distinguished by their growth form, pore sizes and pore patterns (Boschma, 1948; de Weerdt, 1984; Amaral et al., 2008). Millepora alcicornis Linnaeus, 1758 is the only species recorded from across the Atlantic, while three other species are only found in the Caribbean ( $M$. complanata Lamarck, 1816, M. squarrosa Lamarck, 1816 and $M$. striata Duchassaing \& Michelotti, 1864) and three are endemic to Brazil (M. braziliensis Verrill, 1868, M. laboreli Amaral, 2008 and M. nitida Verrill, 1868)

The existence of Millepora at Ascension Island was first mentioned by Irving (2013), who stated that both Millepora alcicornis and $M$. complanata occur in small patches of open area of bedrock' from 8 to $15 \mathrm{~m}$ depth. Although he reported that specimens were collected during the Operation Origin Expedition in 1985, he did not mention their exact locality (Irving, 2013: table 1) and how they were identified. His observations took place over the course of numerous dives, down to a depth of $45 \mathrm{~m}$, reported on in an earlier publication (Irving, 1989), which at the time did not indicate the presence of Millepora. So far, no photographic records were

Corresponding author:

B.W. Hoeksema

Email: bert.hoeksema@naturalis.nl known of Millepora at Ascension and no published reports were available on museum specimens, despite the presence of a sample in the Natural History Museum in London (BMNH 1972.9.1.2) from English Bay, which was donated by the Ascension Historical Society and identified as Millepora alcicornis by Solene Whybrow (H. Zibrowius, personal communication).

As Millepora corals are notoriously difficult to identify (Boschma, 1948; Stearn \& Riding, 1973; Amaral et al., 2002; Clemente et al., 2011; Brown \& Edmunds, 2013), colonies were photographed and a sample for genetic analysis was taken during a recent expedition to Ascension Island. This evidence is used in the present study to supply conclusive information on the identity of this Millepora species as part of Ascension's shallow-water fauna.

\section{MATERIALS AND METHDDS}

During an expedition to Ascension Island in August/ September 2012, coral specimens were photographed in situ and collected by Dr Peter Wirtz during scuba-diving in a depth range of o to $25 \mathrm{~m}$ (Zibrowius et al., 2014).

\section{Material}

RMNH Coel. 40167 from Red Rock, near English Bay (o $7^{\circ} 53.654^{\prime} \mathrm{S} 14^{\circ} 23.676^{\prime} \mathrm{W}$ ), $8 \mathrm{~m}$ depth, 6 September 2012: 8 small fragments $(\sim 1 \mathrm{~cm}$ in size $)$ in $96 \%$ ethanol. Additional material from Ascension was available for morphological study: BMNH 1972.9.1.2 from English Bay (o $7^{\circ} 53^{\prime} \mathrm{S}$ $\left.14^{\circ} 23^{\prime} \mathrm{W}\right), 1971: 4$ dry specimens.

DNA was extracted from specimens preserved in ethanol using the DNeasy Blood and Tissue kit (Qiagen). The $16 \mathrm{~S}$ subunit of the ribosomal RNA was amplified by polymerase 
chain reaction using published primers (Cunningham $\&$ Buss, 1993) and sequenced on an ABI 3130XL gene analyser. The obtained sequences were compared with $16 \mathrm{~S}$ sequences from M. alcicornis from the North and East Atlantic (Bermuda, Colombia, Florida, Panama and Cape Verde Islands) $(\mathrm{N}=$ 10), M. braziliensis $(\mathrm{N}=10), M$. laboreli $(\mathrm{N}=9)$ and $M$. nitida $(\mathrm{N}=10)$ (de Souza, 2013), and Millepora sp. fragments from the Canary Islands, Tenerife, Poris de Abona, $6 \mathrm{~m}, 26$ September 2010, don. A. Brito, RMNH Coel. $39907(\mathrm{~N}=1)$. Pairwise genetic distance was calculated between the Ascension specimen and the 40 Millepora specimens using MEGA v5.2 in order to identify the Ascension specimens to the most similar species. The sequences have been deposited in GenBank ( $M$. alcicornis Ascension Island MA KF871426; $M$ alcicornis Tenerife MT1 KF871427).

Abbreviations: BMNH, The Natural History Museum, London, formerly British Museum (Natural History); RMNH, Naturalis Biodiversity Center, Leiden, formerly Rijksmuseum van Natuurlijke Historie.

\section{RESULTS}

\section{Habitat}

So far Millepora corals observed and sampled at Ascension (RMNH Coel 40167, Figure 1; BMNH 1972.9.1.2, Figure 2) were only found in English Bay and Red Rock at the north side of the island (for maps, see Price \& John, 1980: figure 2; Irving, 2013: figure 16.1). The underwater landscape of English Bay has been described as an area consisting of

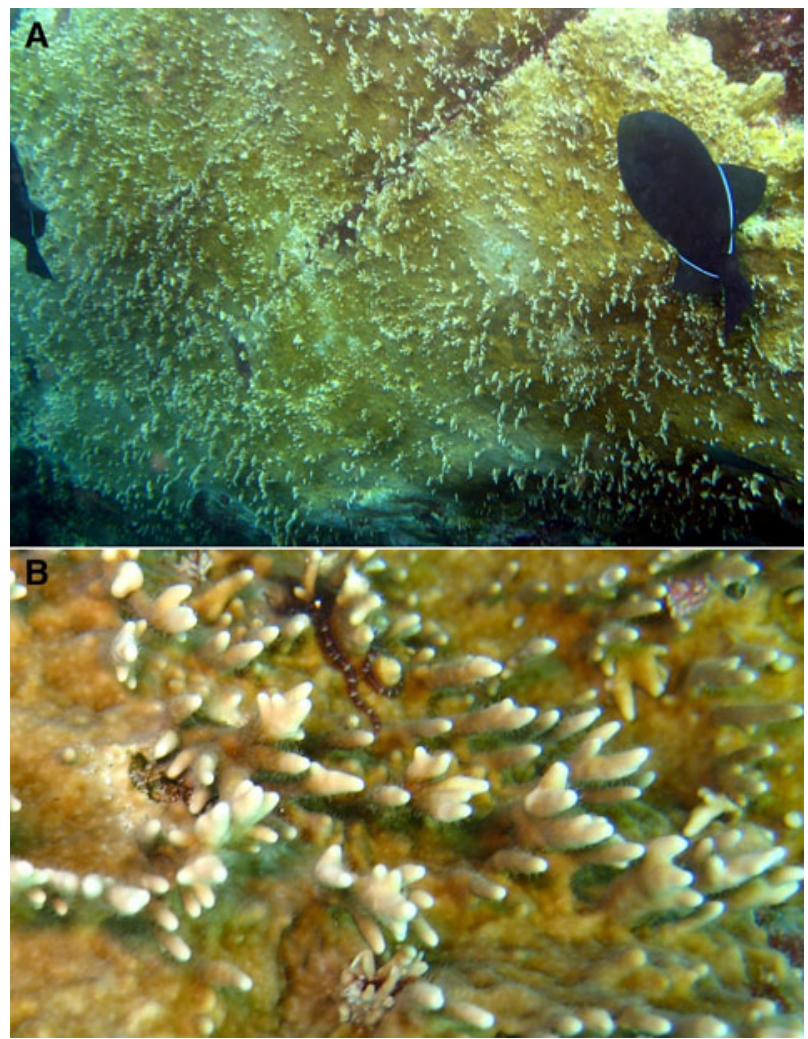

Fig. 1. Millepora alcicornis colony in about $8 \mathrm{~m}$ depth in English Bay, Ascension Island. (A) The black trigger fish (Melichthys niger) in the photo is about $25 \mathrm{~cm}$ long. (B) Close-up. Photos by P. Wirtz. massive outcrops of bedrock with terraces, cliffs, small caves and underhangs (Irving, 2013).

\section{Morphology}

The fragments collected in September 2012 consisted of tiny branch tips, which are unsuitable for identification based on pore patterns (De Weerdt, 1984). The coral colonies themselves, like the one from which the fragments were taken (Figure 1), are large encrusting plates with short, finger-like branches that may be laterally compressed at their tips, a growth pattern typical for M. alcicornis (Boschma, 1948; De Weerdt, 1984). A similar growth form is shown by Millepora specimens that were recently discovered at Tenerife (Clemente et al., 2011; RMNH Coel. 39907). The $\mathrm{BMNH}$ specimens are $2-11 \mathrm{~cm}$ in length and show a low density of relatively small dactylopores (Figure 2), which is typical for M. alcicornis (see De Weerdt, 1984). Owing to their phenotypic variation, identification of milleporids based on morphological criteria is most reliable when a combination of characters is used (De Weerdt, 1984). Sizes of dactylopores $(0.05-0.15 \mathrm{~mm})$ and gastropores $(0.15-0.25)$ in $M$. alcicornis are similar to those in $M$. striata but the density of dactylopores in the former (roughly 50$\left.200 \mathrm{~cm}^{-2}\right)$ is much lower than in the latter $\left(300-500 \mathrm{~cm}^{-2}\right)$ and similar to the density found in $M$. complanata, while the density of gastropores is less useful as a diagnostic character (De Weerdt, 1984). Specimens from Ascension (BMNH, Figure 2$)$ show a low density $\left(\sim 150 \mathrm{~cm}^{-2}\right)$ of the small dactylopores $(\sim 0.10 \mathrm{~mm})$, whereas its gastropores are twice as large in diameter $(\sim 0.20 \mathrm{~mm})$, which agree with data known from M. alcicornis (De Weerdt, 1984). Ampullae, organs in which Millepora medusae are kept (see Lewis, 1991), were not present in the material from Ascension.

\section{Molecular genetics}

The average pairwise genetic distance between the Millepora specimen collected in Ascension Island and individuals of M. alcicornis, M. braziliensis, M. nitida and M. laboreli was found to be $0.0062 \pm 0.0042,0.0786 \pm 0.0015,0.0830 \pm 0$ and $0.0906 \pm 0.0039$ respectively, while for the Millepora specimen from Canary Islands the average pairwise distances

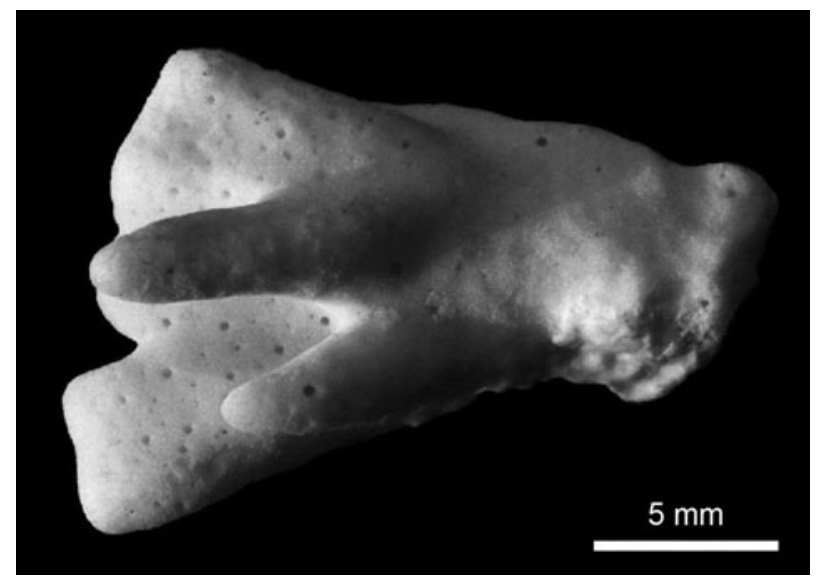

Fig. 2. Small branch of Millepora alcicornis from English Bay (BMNH 1972.9.1.2), showing regeneration at its base. The pores are relatively large in comparison to other Atlantic Millepora species. Photo by H. Zibrowius. 
were $\quad 0.0081 \pm 0.0016, \quad 0.0759 \pm 0.0019, \quad 0.0760 \pm 0$, $0.0870 \pm 0.0022$. The genetic distance between the Millepora specimens from Ascension and Canary Islands was 0.009 . Genetic distance is approximately one order of magnitude lower for $M$. alcicornis, compared with the other three species for both specimens from Ascension and Canary Islands. The most similar sequences (one M. alcicornis individual from Cape Verde and one from Florida) had only one mutational difference from the Ascension specimen. The molecular data confirm the identification of the Ascension and Canary Island specimens as that of $M$. alcicornis.

\section{Conclusion}

Although morphological characters are very variable in Millepora species, based on a combination of branch form, pore density and poor size, the Millepora species at Ascension is most likely M. alcicornis. This finding is supported by molecular evidence.

\section{DISCUSSIDN}

\section{Occurrence}

This second published record of Millepora from Ascension Island, after Irving's (2013), is the first with evidence from the field. Both records are remarkably recent while the BMNH specimens were already collected in 1971, confirming that natural history collections may be important as sources for earlier species records and the reconstruction of previous fauna compositions (Rainbow, 2009; Luttikhuizen \& Dekker, 2010; Hoeksema et al., 2011; Hoeksema \& Wirtz, 2013). An explanation for these scarce records may be that Millepora has a very restricted distribution at the northernmost tip of Ascension Island, or because most previous submarine sampling took place in shallow water, especially in the intertidal zone (compare Price \& John, 1980; Reimer et al., 2014; Zibrowius et al., 2014). English Bay is among the most protected sites to wave exposure in Ascension (Irving, 2013). It is possible that hydrodynamic turbulence and wave action in other localities prevent the settlement of Millepora in shallow water.

\section{Identity}

Based on morphological and genetic analyses, all specimens in the present study were identified as Millepora alcicornis. The earlier record of M. complanata (Irving, 2013) could not be confirmed. In the field, specimens of both species may be hard to separate (Stearn \& Riding, 1973; Brown \& Edmunds, 2013). Evidence suggests that they may form a 'species complex' (Ruiz-Ramos et al., 2014).

\section{Morphology}

The growth form of Millepora alcicornis at Ascension predominantly consists of large crusts with small branches. Although M. alcicornis is generally known to show much ecophenotypic variation, this encrusting shape is relatively most common at shallow depths and on vertical rock surfaces, where it helps to resist wave action (Stearn \& Riding, 1973; De Weerdt, 1981; Edmunds, 1999).

\section{Distribution range}

Millepora alcicornis is the only Millepora species with an amphi-Atlantic distribution range. Millepora spp. are generally known as infrequent breeders and may apply fragmentation as an asexual reproduction strategy (Lewis, 1989, 2006; Edmunds, 1999), favouring short-distance dispersal, which may explain why most Atlantic Millepora species have limited, western Atlantic ranges or very local distributions, as shown by Brazilian endemics (Amaral et al., 2008). In contrast, most Indo-Pacific Millepora species have wide ranges (Boschma, 1948; Razak \& Hoeksema, 2003). It is unclear why M. alcicornis has such a wide range, including not only Ascension but also the Cape Verde Islands (Boekschoten \& Best, 1988) and the Canary Islands (present results), from where it was reported as recently introduced (Clemente et al., 2011). Although M. alcicornis has been recorded from very shallow depths (Lewis, 2006), it may be rare in the intertidal zone (Stearn \& Riding, 1973). Since Millepora corals are able to settle as crusts on various substrates (De Weerdt, 1981; Lewis, 2006), species that would be able to survive well in shallow water could also be successful as rafters (Hoeksema et al., 2012). Comparative studies on the reproduction, dispersal, settlement and phylogeography of the various Millepora species are required (cf. Nunes et al., 2011) in order to clarify the occurrence of $M$. alcicornis as a single Millepora species at Ascension and islands in the eastern Atlantic.

\section{ACKNOWLEDGEMENTS}

This paper was made possible by participation by Dr Peter Wirtz in the August-September 2012 expedition to Ascension Island on invitation by Dr Paul Brickle. We thank him for donating the coral fragments, the in situ photographs and locality information. The funding for this work came from a grant to the Shallow Marine Surveys Group from the Darwin Initiative (EIDCFo12). Work by F.L.D. Nunes was supported by a grant from the Regional Council of Brittany, from the European Funds (ERDF) and supported by the 'Laboratoire d'Excellence' LabexMER (ANR-10-LABX-19) and co-funded by a grant from the French government under the program 'Investissements d'Avenir'. We are grateful to the Shallow Marine Surveys Group and the South Atlantic Environmental Research Institute for organizing the expedition. We are also very grateful to the Ascension Island Government and the members of staff at the Conservation Centre and Ascension Island Dive Club for their cooperation, accommodation and hospitality. We are grateful to British Forces South Atlantic Islands for their logistical support. Dr Alberto Brito donated Millepora fragments from Tenerife, Canary Islands, to Naturalis for identification and biogeographic comparison. Dr Helmut Zibrowius provided photographs of $\mathrm{BMNH}$ specimens. Constructive remarks from two anonymous reviewers helped to improve the text.

\section{REFERENCES}

Amaral F.D., Broadhurst M.K., Cairns S.D. and Schlenz E. (2002) Skeletal morphometry of Millepora occurring in Brazil, including a 
previously undescribed species. Proceedings of the Biological Society of Washington 115, 681-695.

Amaral F.M.D., Steiner A.Q., Broadhurst M.K. and Cairns S.D. (2008) An overview of the shallow-water calcified hydroids from Brazil (Hydrozoa: Cnidaria), including the description of a new species. Zootaxa 1930, 56-68.

Boekschoten G.J. and Best M.B. (1988) Fossil and recent shallow water corals from the Atlantic islands off Western Africa. Zoologische Mededelingen Leiden 62, 99-112.

Boschma H. (1948) The species problem in Millepora. Zoologische Verhandelingen Leiden 1, 1-115 pls. 1-15.

Brown D. and Edmunds P.J. (2013) Long-term changes in the population dynamics of the Caribbean hydrocoral Millepora spp. Journal of Experimental Marine Biology and Ecology 441, 62-70.

Cairns S.D., Hoeksema B.W. and Van der Land J. (1999) List of extant stony corals. Atoll Research Bulletin 459, 13-46.

Clemente S., Rodríguez A., Brito A., Ramos A., Monterroso Ó. and Hernández J.C. (2011) On the occurrence of the hydrocoral Millepora (Hydrozoa: Milleporidae) in the subtropical eastern Atlantic (Canary Islands): is the colonization related to climatic events? Coral Reefs 30, 237-240.

Cunningham C.W. and Buss L.W. (1993) Molecular evidence for multiple episodes of paedomorphosis in the Family Hydractiniidae. Biochemical Systematics and Ecology 21, 57-69.

de Souza J.N. (2013) Endemismo e conectividade de corais de fogo (Millepora spp.) no Oceano Atlântico. MSc thesis. Universidade Federal de Santa Catarina, Brazil.

De Weerdt W.H. (1981) Transplantation experiments with Caribbean Millepora species (Hydrozoa, Coelenterata), including some ecological observations on growth forms. Bijdragen tot de Dierkunde 51, 1-19.

De Weerdt W.H. (1984) Taxonomic characters in Caribbean Millepora species (Hydrozoa, Coelenterata). Bijdragen tot de Dierkunde 54, 243-262.

Edmunds P.J. (1999) The role of colony morphology and substratum inclination in the success of Millepora alcicornis on shallow coral reefs. Coral Reefs 18, 133-140.

Hoeksema B.W. and Wirtz P. (2013) Over 130 years of survival by a small, isolated population of Favia gravida corals at Ascension Island (South Atlantic). Coral Reefs 32, 551.

Hoeksema B.W., Roos P.J. and Cadée G.C. (2012) Trans-Atlantic rafting by the brooding reef coral Favia fragum on man-made flotsam. Marine Ecology Progress Series 445, 209-218.

Hoeksema B.W., Van der Land J., Van der Meij S.E.T., Van Ofwegen L.P., Reijnen B.T., Van Soest R.W.M. and De Voogd N.J. (2011) Unforeseen importance of historical collections as baselines to determine biotic change of coral reefs: the Saba Bank case. Marine Ecology 32, 135-141.
Irving R.A. (1989) A preliminary investigation of the sublittoral habitats and communities of Ascension Island, South Atlantic. Progress in Underwater Science 13, 65-78.

Irving R.A. (2013) Ascension Island's hermatypic but non-reef building corals. In Sheppard C.R.C. (ed.) Coral Reefs of the United Kingdom Overseas TerritoriesCoral Reefs of the World 4. Dordrecht: Springer, pp. 213-221.

Lewis J.B. (1989) The ecology of Millepora. Coral Reefs 8, 99-107.

Lewis J.B. (1991) The ampullae and medusae of the calcareous hydrozoan Millepora complanata. Hydrobiologia 216-217, 165-169.

Lewis J.B. (2006) Biology and ecology of the hydrocoral Millepora on coral reefs. Advances in Marine Biology 50, 1-55.

Luttikhuizen P. and Dekker R. (2010) Pseudo-cryptic species Arenicola defodiens and Arenicola marina (Polychaeta: Arenicolidae) in Wadden Sea, North Sea and Skagerrak: morphological and molecular variation. Journal of Sea Research 63, 1-17.

Nunes F.L.D., Norris R.D. and Knowlton N. (2011) Long distance dispersal and connectivity in amphi-Atlantic corals at regional and basin scales. PLoS ONE 6, e22298.

Price H. and John D.M. (1980) Ascension Island, south Atlantic: a survey of inshore benthic macroorganisms, communities and interactions. Aquatic Botany 9, 251-278.

Rainbow P.S. (2009) Marine biological collections in the 21st century. Zoologica Scripta 38(Suppl. 1), 33-40.

Razak T.B. and Hoeksema B.W. (2003) The hydrocoral genus Millepora (Hydrozoa: Capitata: Milleporidae) in Indonesia. Zoologische Verhandelingen Leiden 345, 313-336.

Reimer J.D., Lorion J., Irei Y., Hoeksema B.W. and Wirtz P. (2014) Ascension Island shallow-water zoanthids (Zoantharia: Hexacorallia: Cnidaria) and their zooxanthellae (Symbiodinium). Journal of the Marine Biological Association of the United Kingdom. doi:10.1017/ Soo25315414000654.

Ruiz-Ramos D.V., Weil E. and Schizas N.V. (2014) Morphological and genetic evaluation of the hydrocoral Millepora species complex in the Caribbean. Zoological Studies 53, 4. doi:10.1186/1810-522X-53-4.

Stearn C.W. and Riding R. (1973) Forms of the hydrozoan Millepora on a Recent coral reef. Letheia 6, 187-200.

and

Zibrowius H., Wirtz P., Nunes F.L.D., Hoeksema B.W. and Benzoni F. (2014) Shallow-water scleractinian corals of Ascension Island. Journal of the Marine Biological Association of the United Kingdom $97,713-725$.

\section{Correspondence should be addressed to:}

B.W. Hoeksema

Department of Marine Zoology, Naturalis Biodiversity Center, P.O. Box 9517, 2300 RA Leiden, the Netherlands email: bert.hoeksema@naturalis.nl 